\title{
Sagaer i samtiden: Arne Magnussons storslåede arv
}

Inovember 2013 fejredes den store islandske händskriftsamler, grundlaggeren af Den Arnamagnaanske Samling, professor Arne Magnussons 350-ärs fodselsdag både i Island og i Danmark. I den anledning holdt forfatteren til denne artikel jubilaumsforelasning pa Islands Universitet d. 12. november 2013 og igen ved Den Arnamagnaanske Kommissionsfejring af jubilaet på Københavns Universitet d. 22. november 2013. Forelasningen bringes her som artikel. Den behandler på baggrund af en oversigt over tidligere oversattelser og udgaver af de islandske sager $i$ Norden to store igangverende projekter, hvoraf det ene afsluttes i 2014, og hvoriforfatteren er hovedaktor.

af universitetslektor, ph.d. Annette Lassen, Den Arnamagnaanske Samling, Københavns Universitet

$\mathrm{H}$ vis den danske historie skulle skrives uden brug af islandske beretninger fra middelalderen blev sagnhistorien ganske tynd, kedelig og kort. Hvis danske romantiske forfattere ikke havde kunnet dykke ned i skattekisten af Islands middelalderskrifter, så havde vi i dag ikke haft Oehlenschlägers berømte og eddainspirerede digt, Guldhornene, læsedramaet Baldur hin gode, sørgespillet Hakon Jarl hin rige, eller dramaet Kjartan og Gudrun, for nu at nævne nogle få eksempler fra Oehlenschlägers forfatterskab. Hvis eddaer og sagaer ikke var overleveret, så var Grundtvig såmænd også sluppet for sin asarus. Ja, havde vi ikke haft Islands middelalderlitteratur, så måtte danske fodboldentusiaster synge en ganske anden sang på ramperne før landskamp end Der er et yndigt land, Oehlenschlägers sang, hvor Danmark omskrives med kenningen Frejas sal, og hvor guderne Brage og Mimer optræder - for ikke at nævne Alfader, et alternativt navn for Odin med rødder i islandsk middelalder. Måske havde H.C. Andersen heller aldrig fået stipendium til at gå i latinskole og studere et år ved Københavns
Universitet, hvis det ikke havde været for hans brug af Finn Magnussons oversættelse af eddadigtene $\mathrm{i}$ hans oldnordiske tragedie Alfsol, som H.C. Andersen som 17-årig sendte til Knud Lyhne Rahbek og direktionen for Det kongelige Teater. Rahbek afviste skuespillet, fordi det "på ingen maade egner sig til Skuepladsen", men han anbefalede at give den unge Andersen stipendium til at uddanne sig, fordi der i "Volas første scener" findes "enkelte Glimt". Og netop Vola havde Andersen hentet i Finn Magnussons edda-oversættelse; hun er vølven i Volvens spådom, Völuspá. ${ }^{2}$

Islands middelalderlitteratur er bevaret og overleveret i håndskrifter. $\mathrm{Da}$ dagens fødselar blev født d. 13. november 1663 havde det lærde samfund i Norden forstået vigtigheden af den islandske middelalderlitteratur - den norrøne renæssance var så at sige i fuldt sving. Arne Magnussons store bedrift var - ud over hans særdeles vigtige introduktion af den kritiske tænkning i norrøne studier - hans utrættelige indsamling af håndskrifter, folianter og fragmenter, papir og pergament. Næsten alt havde hans interesse, og 
han indsamlede også mange håndskrifter på andre sprog end islandsk. Parallelt med indsamlingen af håndskrifter brugte han sin tid på at organisere sin samling, så fremtidige forskere kunne anvende den. Som dværge på Arne Magnussons skuldre, for nu at anvende Bernhard af Chartres berømte dictum (sicut nani super humeros gigantum), er det derfor vores kærkomne pligt at tage vare på, udforske, udgive og formidle denne arv. Man interesserer sig i dag både for håndskrifterne som fysiske objekter; de studeres som artefakter, vigtige vidnesbyrd om kultur- og socialhistorie; og man studerer dem som åndsværker, deres tekster som vidnesbyrd om en del af den europæiske sprog-, kultur-, idé- og litteraturhistorie. Men der er kun få, som kan læse det gamle islandske sprog og endnu færre, som kan læse håndskrifternes tekster. Sådan var det også i Arne Magnussons tid. Og Arne Magnusson var klar over, at de skulle udgives og oversættes; han oversatte selv flere sagaer til gavn for andre lærde. Det er en sand tanke, som man i dag tilskriver Goethe, at verdenslitteraturen skabes i oversættelsen til andre sprog. Håndskrifternes sagaer skal således ikke bare udgives, men også oversættes, så alle kan få del i arven, for håndskrifterne kommer alle ved, de er ikke kun en islandsk arv, ikke engang en dansk-islandsk eller nordisk arv, de er en verdensarv, hvad der blev fastslået i 2009, da Arne Magnussons håndskriftsamling blev optaget på Unescos Memory of the World-register.

Arne Magnussons æaldre samtidige biskop Brynjolf Sveinsson skrev engang: "At låse håndskrifter inde i udenlandske biblioteker, hvor ingen vil forstå dem [...] er ikke at bevare dem, men at tilintetgøre dem".3 Samlingen skal, så at sige, bringes ud af boksen, hvori den opbevares i Danmark

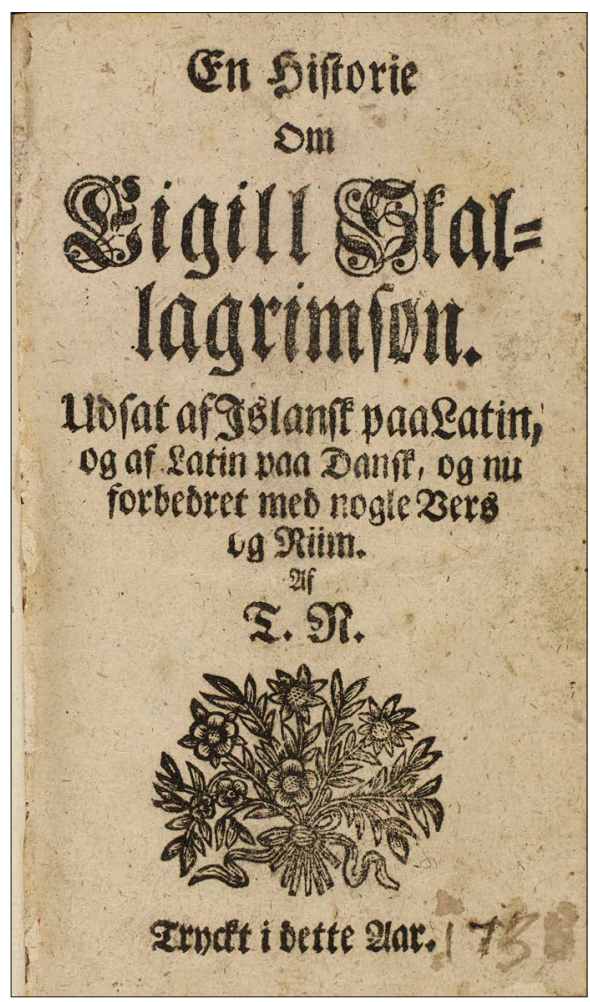

Truid Nitter (overs.): En Historie om Eigill Skallagrimsøn, 1738.

og Island; den skal formidles, for litteratur bliver først levende, når den bliver læst. Det er denne formidling af Arne Magnussens arv via nyoversættelser af islandske sagaer, som jeg vil tale om i dag.

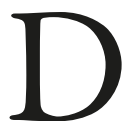
er udføres i disse år to store oversættelsesprojekter. Det ene er en oversættelse af alle islændingesagaer til dansk, norsk og svensk; projektet sker på islandsk initiativ, det indledtes $i$ 2008 og er nu meget nær ved at kunne afsluttes. Der er tale om et korpus på ca. 2.600 sider, 40 sagaer og 49 totter og et projekt, der involverer 14 oversættere. Jeg 
er selv redaktør for de danske oversættelser, og Merete Pryds Helle er skønlitterær konsulent. De danske oversættelser finansieres primært af A.P. Møller Fonden og Augustinus Fonden. Det andet projekt er en samlet oversættelse til dansk af oldtidssagaerne, som først for nyligt er gået i gang. Dette projekt sker på mit initiativ, og det involverer fire oversættere.

Sagalitteraturen er både mangfoldig og uudtømmelig. Gruppen af originale islandske sagaer består af islændingesagaer (sagaer om islandske helte), kongesagaer, oldtidssagaer eller fornaldarsagaer (dvs. sagaer om Nordens sagntid), samtidssagaer, riddersagaer og bispesagaer. Selvom der er en lang og fin tradition for oversættelser af sagaer i Danmark, har kun en brøkdel af dette store korpus været formidlet $\mathrm{i}$ oversættelser for danske læsere.

Allerede i løbet af 1500-tallet blev der i Norge foretaget oversættelser af de norske kongers sagaer. Herefter fulgte hurtigt en interesse for oldtidssagaerne, som man (dog med en markant undtagelse af dagens fødselar) i 1600-tallet anså for at være troværdige historiske beretninger om Nordens oldtid. I 1660'erne udkom der i Sverige flere oldtidssagaer på originalsproget og med oversættelse til svensk og/eller latin. De første udgaver af islændingesagaer udkom først $i$ anden halvdel af 1700-tallet. Fra 1772 og frem udkom en række islændingesagaer på originalsproget, udgivet af Den Arnamagnæanske Kommission og Det nordiske Oldskrift-Selskab i København. Udgaverne indeholdt oversættelser til latin på nær en udgave af Njals saga. ${ }^{4}$ Allerede i 1738 var Egils saga udkommet i oversættelse til dansk ved Truid Nitter; den tidlige interesse for denne saga skal ses i lyset af, at handlingen i højere grad udspilles hos

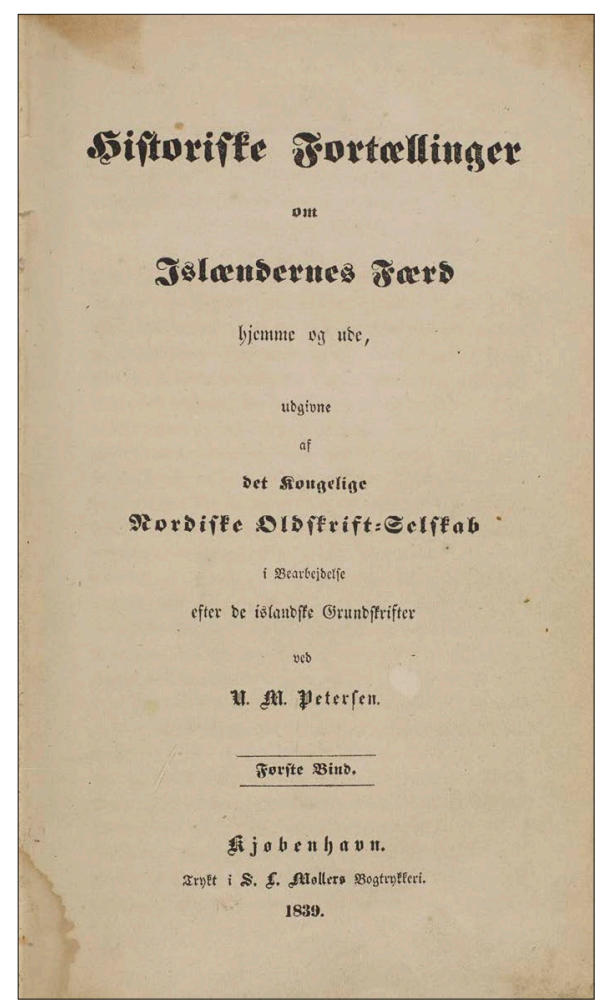

N.M. Petersen (overs.): Historiske Fortællinger om Islændernes Færd hjemme og ude, bd. 1-4, 1839-1844.

konger end islandske bønder. Den første klassiske islændingesaga, der oversattes, var Gunlogs saga, som udkom 1778-1779; oversætteren var den autodidakte officer og litterat Werner Abrahamson (17441812). 1819-1821 udkom det første samleværk med islændingesagaer, $\mathrm{da}$ Knud Lyhne Rahbek udgav to bind med oversættelser. Her udkom Njals saga for første gang på dansk med den talende titel De ulige Hustruer eller Gunnars og Nials Endeligt, og Laksdolernes saga (med titlen Den Døvstumme eller Kongedatteren og hendes $Æ t$, dvs. om den irske kongedatter Melkorka, Olav Påfugl og Kjartan). 


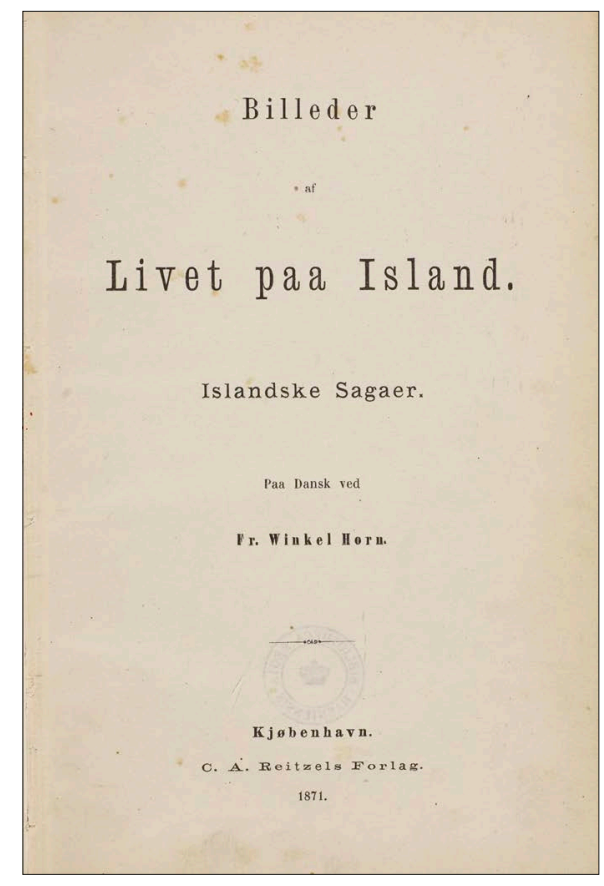

Fr. Winkel Horn (overs.): Billeder af Livet paa Island: Islandske Sagaer, bd. 1-3, 1871 1876.

I årene 1839-44 udkom N.M. Petersens oversættelser af 10 islændingesagaer i fire bind med titlen Historiske Fortellinger om Islandernes Ferd hjemme og ude. I modsætning til de øvrige oversættelser af islændingesagaer i 1800-tallet har N.M. Petersens oversættelser haft en særlig betydning for genrens reception i Danmark. Værket er udkommet i seks forskellige udgaver, og nogle af disse er genoptrykt flere gange, mig bekendt senest i 2003 , dog med visse ændringer i teksten. ${ }^{5} 1871$ 1876 kom igen et samleværk, tre bind, med oversættelser af 16 islændingesagaer, oversat af Fr. Winkel Horn, Billeder af Livet paa Island. Dette udvalg udgjorde et værdigt supplement til N.M. Petersens samling, men er ikke blevet genudgivet.
I 1926-1927 blussede en voldsom sagastrid i dagbladet Politiken. Den islandske skønlitterære forfatter, Gunnar Gunnarsson, som dengang boede i Danmark og var en af de mest populære forfattere i Norden, indledte i en kronik d. 6.12.1926 i Politiken et angreb mod sproget i en ny genudgivelse af N.M. Petersens oversættelser. Sproget i oversættelsen var ifølge Gunnar Gunnarsson "vredet af Lave, knudret og klodset, mishandlet til den rene Ynkelighed". Det var "en afskyelig Vanskabning af et Sprog”. Det var to velkendte professorer ved Københavns Universitet, nemlig Finnur Jónsson og Verner Dahlerup, der havde redigeret nyudgivelsen. Gunnar Gunnarsson benyttede sit angreb til at plædere for en nyoversættelse af islændingesagaerne, som skulle foretages af skønlitterære forfattere med sans for sproget. Denne nyoversættelse blev også en realitet. Årene 1930-31 udkom 11 sagaer i tre bind, oversat af syv digtere, en filolog og en litterat: Johannes V. Jensen, Tom Kristensen, Thøger Larsen, Knud Hjortø, Hans Kyrre, Vilhelm Andersen, Johannes Brøndum-Nielsen og Gunnar Gunnarsson selv. Udgaven var et pragtværk med tegninger af Johannes Larsen. Som N.M. Petersens oversættelse i sin tid var også denne ambitiøs; den blev udgivet under videnskabelig medvirken af Jón Helgason og Brøndum-Nielsen. Den redaktionelle ledelse bestod af Hans Kyrre, Johannes V. Jensen og Gunnar Gunnarsson. Også denne udgave er udkommet gentagne gange, tredje udgave i 2007.

Trods mængden af oversættelser har en række islændingesagaer aldrig været oversat til dansk, og mange af de sagaer, som er oversat, foreligger i gamle og utilstrækkelige gengivelser. I mange tidligere 


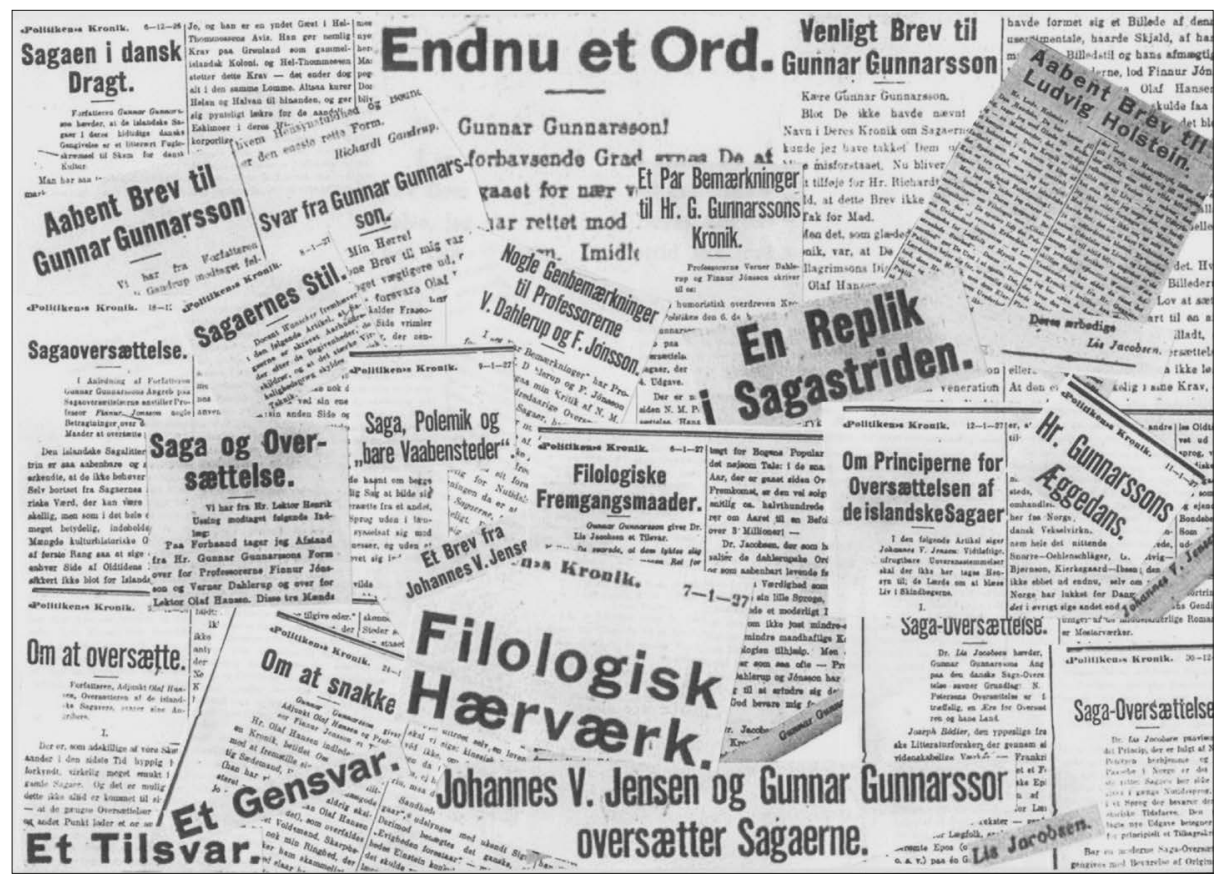

"Sagastriden" i Politiken december 1926 - januar 1927. Collage ved forfatteren.

oversættelser er sagateksten drastisk beskåret. Det har ofte været smagsvurderinger og æstetiske domme, som har haft betydning for, hvilke sagaer der er blevet oversat og hvor oversætterne har skåret. For de ældste oversættelsers vedkommende havde sagaernes historicitet afgørende betydning, men i praksis anså man ofte en sagas manglende historicitet som udtryk for en "fordærvet smag". For N.M. Petersen var Njals saga "fuldendt" og kunne "med al Ret tildrage sig vor Beundring", men allerede Laksdølernes saga havde over sig "noget vel snaksomt, langtrukkent og flæbende i Fortællemaaden", Finbues saga var for Petersen et “Æventyr”, Grettes saga forkortede han, da den "i [...] sin oprindelige Skikkelse [vidner] om en [...] fordærvet Smag”. Værst lød hans dom over Svarvadsdølernes saga, som han også for- korter: Den "hører ikke til de bedste Sagaer, ikke engang til de gode". ${ }^{8}$ Den hårde dom ramte især de yngre sagaer, og det er da også dem, der gentagne gange er blevet udeladt i oversættelser af islændingesagaer. Det er i øvrigt den samme modvilje mod det "æventyrlige", "fabelagtige" og "usandsynlige”, som har betydet, at størstedelen af sagaerne om Nordens oldtid, oldtidssagaerne, endnu aldrig har været oversat til dansk. Fantastikken, det groteske og den fabulerende fortælleglæde er nemlig stiltræk, som de yngre islændingesagaer har til fælles med mange oldtidssagaer. Disse stiltræk kan da også få enhver tænkende læser til at stille spørgsmålstegn ved deres kvalitet som historiske vidnesbyrd. Således sagde for eksempel dagens fødselar i et brev til den kongelige historiograf, Thormod Torfæus, at "han holdt meget 


\section{DE ISLANDSKE SAGAER}

PAA DANSK VED SELSKABET TIL UDGIVELSE

AF ISLANDSKE SAGAER

MED TEGNINGER FRA ISLAND AF

JOHANNES LARSEN

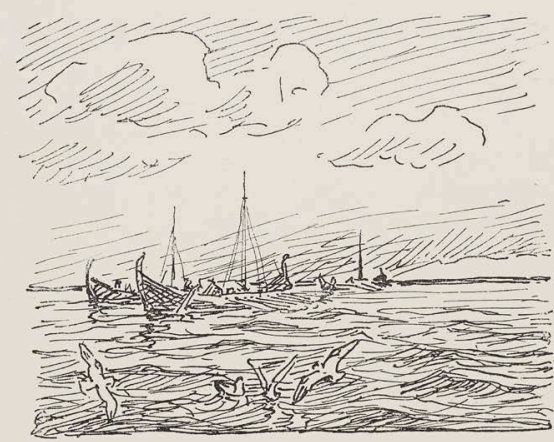

GYLDENDALSKE BOGHANDEL · NORDISK FORLAG KØBENHAVN · MCMXXX

Hans Kyrre, Johannes V. Jensen og Gunnar Gunnarsson (red.): De islandske Sagaer, bd. 1-3, 1930-1931. 
lidt af" en lang række oldtidssagaer ("Eg helld miög lited af Hrolfssögu Gautrekssonar, Bosasögu [...] et similibus" ${ }^{\prime \prime}$ ). Men selvom mange både ældre og yngre islændingesagaer og oldtidssagaer slet og ret er elendige vidnesbyrd om mulige historiske begivenheder, så er de alligevel fremragende litteratur og fabelagtige vidnesbyrd om kultur- og litteraturhistorie og om middelalderens reception af Nordens oldtid.

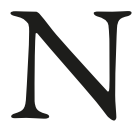
år de nye oversættelser af islændingesagaerne udkommer, bliver det således første gang danske læsere kan få glæde af for eksempel Sagaen om Den Snu Rav og Guld-Tores saga. Sagaen om Den Snu Rav tilhører den europæiske rævelitteratur; det er en tempofyldt og munter beretning, for nylig karakteriseret som et stykke science fiction, idet hovedpersonen konstruerer de mest fantastiske maskiner..$^{10}$ I Guld-Tores saga skaffer hovedpersonen sig derimod en skat i en dragegrotte i det nordlige Norge, og til sidst i fortællingen forvandler han sig til en drage for at lægge sig på sin skat. Andre sagaer, som findes i oversættelse, for eksempel Flomandenes saga, er i dag i praksis uopdrivelige. Den blev oversat til dansk første gang af Børge Thorlacius og udkom i 1809. Denne lidt glemte saga indeholder ellers nogle af de mest uforglemmelige scener i hele korpusset af islændingesagaer. Helten Torgils er draget til Grønland med sin familie, hvor de er ude af stand til at finde de bebyggede områder, hvorfor de dør af sult og sygdomme. En dag, da Torgils har udforsket indlandsisen, finder han sin kone stukket ihjel hjemme i huset. Det er kun kort tid, efter at hun har født en lille dreng. Mændene hører en gurglende lyd fra mørket; det er det spæde barn, der forsøger at drikke mælk ved den døde mors bryst. Torgils skærer sig nu i brystet og malker. Først kommer der blod ud, men efter nogen tid kommer en hvidlig væske. På den opføder han sin lille dreng. Drengen vokser op hos de tre overlevende mænd, og han bliver en stoisk lille fyr, men kommer ulykkeligvis af dage, da det endelig lykkes dem at forlade Grønland og sejle tilbage mod Island. De kommer ud i en frygtelig storm, og en bølge skyller drengen udenbords, men han kastes tilbage på skibet igen af en anden bølge og udbryder da: "Nu skvulper det godt nok, far," hvorpå han dør (kap. 28). ${ }^{11}$ Faren er ude af sig selv af sorg og nægter at give liget fra sig, hvad der selvfølgelig er ukristent. Hans rejsefæller narrer ham væk og begraver drengen i kristen jord. Torgils siger nu de uforglemmelige ord, at han fra da af aldrig vil bebrejde kvinder, at de elsker deres brystbørn højere end andre.

Islændingesagaernes mandlige helte har generelt en særdeles ømskindet ære, især hvis de bliver udfordret på deres maskulinitet. Når Njal bliver kaldt skægløs og hans sønner for møgskæg, fordi deres skæg kun vokser ved påstået brug af gødning, er de nødt til at tage hævn. Hånen tager udgangspunkt i Njals innovative landbrug, hvor der anvendes gødning, men der er også tale om nidbeskyldninger, en stereotyp og symbolsk fremstilling af mænd som kvinder eller ikke-mand. Men islændingesagaernes verden er ikke sorthvid. I Flomandenes saga er kønnet næsten elastisk. Torgils kan opfostre sin søn, give ham bryst, uden at blive en mindre mand af det. Omvendt ser man også en kraftkarl af en kvinde i Sagaen om Bärd Snefjeldsas, en saga, der hidtil kun har været oversat til dansk i små brudstykker i 1800-tallet. Her 


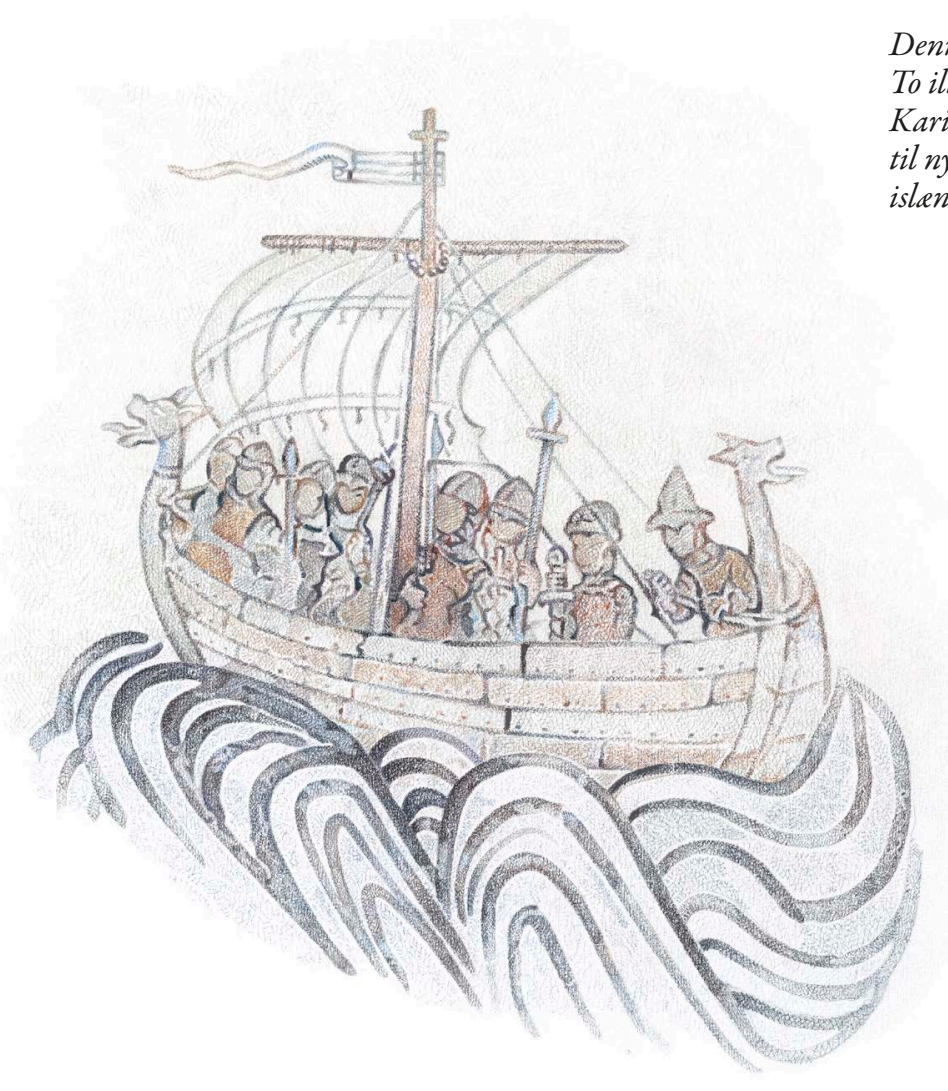

nedkæmper Bårds datter Helga trolde med sin elsker på Grønland, og da en nordmand senere forsøger at komme op i sengen til hende, hvor hun sidder, smuk og kun iført sin særk, får han kærligheden at føle: "De kom op at slås, og det endte med, at Ravns højre arm og venstre ben blev brækket" (kap. 7).

Selv de sagaer, som vi synes, at vi kender bedst, har vi nogle gange aldrig rigtigt læst. Njals saga har aldrig før været oversat til dansk i sin helhed. Oversætterne har hidtil udeladt passager, fordi de enten var for sjofle, besværlige, langtrukne eller irrelevante. Det er evident, at en sådan skalten og valten med originalteksten ikke lever op til vore dages krav til oversættelser af ældre tekster. I de nye sagaoversættelser følges originalteksten med dens dyder og lyder, idet begge dele anses for interessante i kulturhistorisk forstand eller i det mindste autentiske. Derfor vil man hverken finde omarbejdninger eller udeladelser i de nye oversættelser.

De nye oversættelser af islændingesagaer udkommer i foråret 2014 ved Saga Forlag på Island. De vil blive fulgt til dørs af illustrationer af billedkunstneren Karin Birgitte Lund. Karin Birgitte Lunds billeder vil repræsentere 


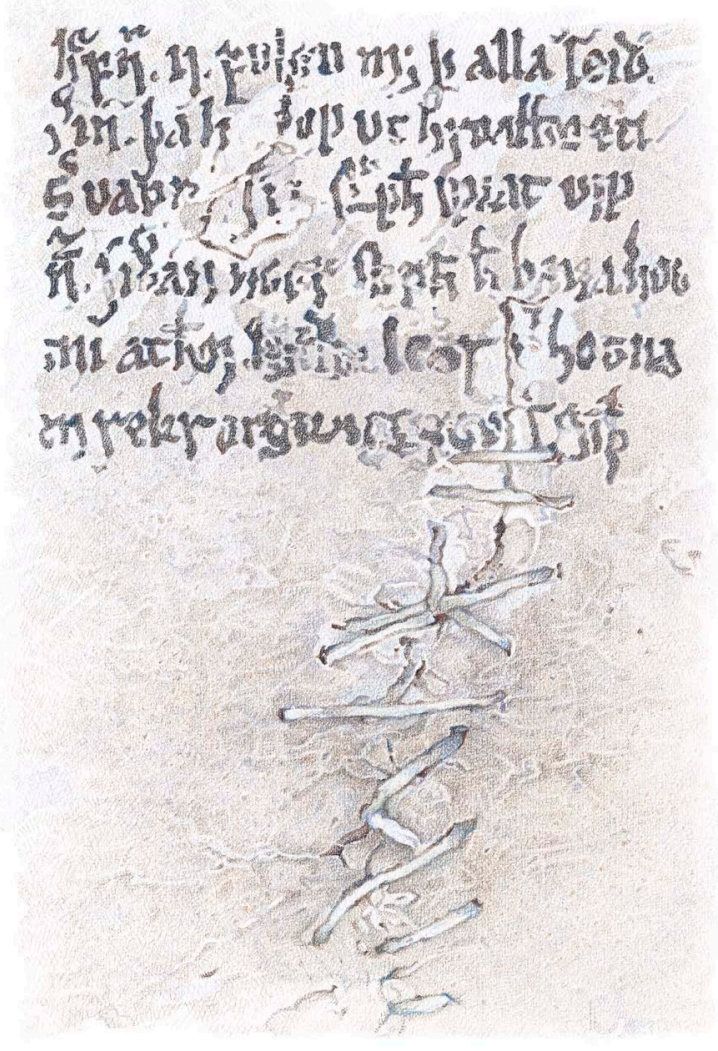

eksisterende motiver fra Island, Norge, Sverige og Danmark fra vikingetid og middelalder. Billederne vil tage udgangspunkt i våben, billedsten, stavkirker, kalkmalerier og ikke mindst motiver fra middelalderens islandske håndskrifter. Via kunstnerens fortolkning vil de give et indblik i denne tids for os fremmede og spændende æstetik.

Jeg får tit henvendelser fra utålmodige og interesserede danske læsere, som spørger til sagaoversættelserne. Der skal mere end én genre til for at mætte disse sagahungrende danskere. Så når islændingesagaerne er udkommet, er det, som omtalt, ikke slut. En langsom pen vil da også løbe tør, før sagaerne er slut, for nu at parafrasere en passage i epilogen i oldtidssagaen om Rolf Gøtrekssøn. ${ }^{12}$

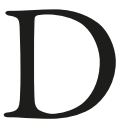
et bringer mig til det andet store oversættelsesprojekt, en samlet oversættelse af oldtidssagaerne. Mens islændingesagaerne handler om islandske helte og primært foregår på Island, handler oldtidssagaerne om Nordens sagntid, om danske, norske og svenske sagnhelte som Sigurd Favnersbane, Ragner Lodbrog, Rolf Krake og Ganger-Rolf. Oldtidssagaerne er befolket 
med guder, skjoldmøer, bersærker, vikinger, konger og kloge dronninger. Siden middelalderen har de spillet en stor rolle for dansk historieskrivning; en stor del af fortællingerne i de første ni bøger af Saxos Gesta Danorum stammer for eksempel fra islandske oldtidssagaer. Det er således på høje tid, at dette korpus formidles for danske læsere i sin helhed.

Når denne sagagruppe har været negligeret, er det, fordi disse sagaer efter kildekritikkens indtog stort set mistede deres betydning som historiske kilder. I romantikken ansås genren for rå og ubearbejdet, men netop råheden gav digterne mulighed for at skabe nyt. Senere, med realismens gennembrud, revurderedes sagagenrerne. Islændingesagaerne ansås nu for den mest vellykkede genre, mens de fantastiske - eller ofte utroværdige oldtidssagaer ansås for dårlig litteratur, en slags middelalderens kiosklitteratur, som en god kollega engang udtrykte det. Men de senere år har både filologer og litterater anerkendt, at oldtidssagaerne er læseværdig verdenslitteratur - de er gode historier. Og i middelalderen var de højkulturel litteratur, sagaer, der var konger - og dronninger - værdige. ${ }^{13}$ Oldtidssagaerne udgør, som islændingesagaerne, en meget broget gruppe af tekster: Nogle af de ældste er rå og tentative og synes at være udsprunget af eddadigte, mens yngre oldtidssagaer, ofte velkomponerede digterværker, synes at være blevet til i miljøer lig dem, der f.eks. fostrede Boccaccios og Chaucers værker.

Allerede i årene 1821-1826 udgav den danske filolog Carl Christian Rafn et samleværk med oversættelser af bl.a. 14 oldtidssagaer i en flerbindsudgave med titlen Nordiske Kampe-Historier. 1829-30 udgav Rafn oldtidssagaerne på originalsproget $\mathrm{i}$ tre bind i København; denne udgave, med titlen Fornaldar Sögur Nordrlanda, konstituerede og navngav genren. De samme år udkom en øget udgave af Rafns oversættelser, nu 17 sagaer og nogle kortere tekster med titlen Nordiske Fortidssagaer. Planen var, at de tre bind skulle indeholde oversættelser af netop de sagaer, som blev udgivet på originalsproget, men Rafn fraveg beslutningen om at udgive dem alle, fordi han fandt, at flere af sagaerne var for eventyrlige, og at de betragtet "fra den poetiske Side" ikke havde nogen "besynderlig Fortrinlighed". ${ }^{14}$ Situationen er i dag ikke meget bedre end på Rafns tid. Mange af oldtidssagaerne er stadig ikke blevet oversat til dansk, hvad der f.eks. gælder de kunstnerisk fremragende Sagaen om den enarmede Egil og Asmund Berserkerbane, Rolf Gotrekssøns saga og Ganger-Rolfs saga. Andre oldtidssagaer har derimod opnået klassikerstatus og er blevet oversat flere gange, for eksempel Ragnar Lodbrogs saga og Volsungernes saga. I det nye projekt oversættes alle 30 oldtidssagaer og en række kortere tekster, der anses for at høre til gruppen. For alle oversættelsers vedkommende gælder det, at de vil følge teksten i ét håndskrift, når det er muligt, så læseren ikke præsenteres for en tekst, som ikke eksisterede i middelalderen. Til gavn for dette projekt knyttes det til et igangværende forsknings- og udgivelsesprojekt på Den Arnamagnæanske Samling i København, som er finansieret af Velux Fonden, ledes af Matthew Driscoll, og som netop fokuserer på disse sagaer.

Oldtidssagaerne vil udkomme i otte bind i løbet af de næste fire år ved Gyldendal, og de vil være illustreret af kunstneren Peter Brandes. Hans illustrationer vil bestå af træsnit. Bøgerne, som Brandes også layouter, bliver smukke; de skal have 


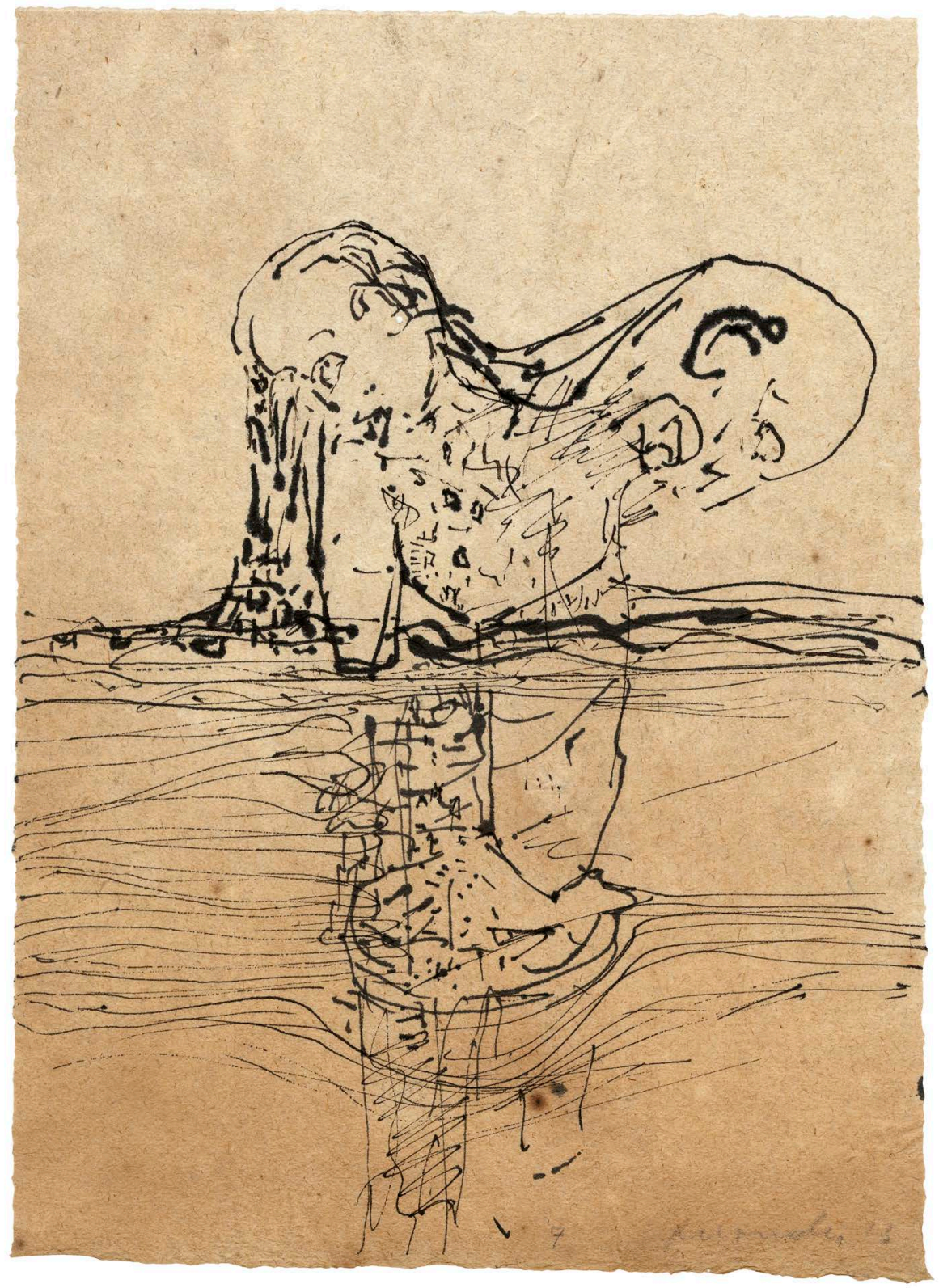

Illustration af Peter Brandes til oversattelsen af oldtidssagaerne.

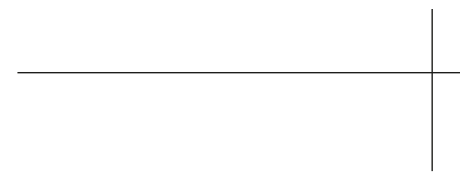




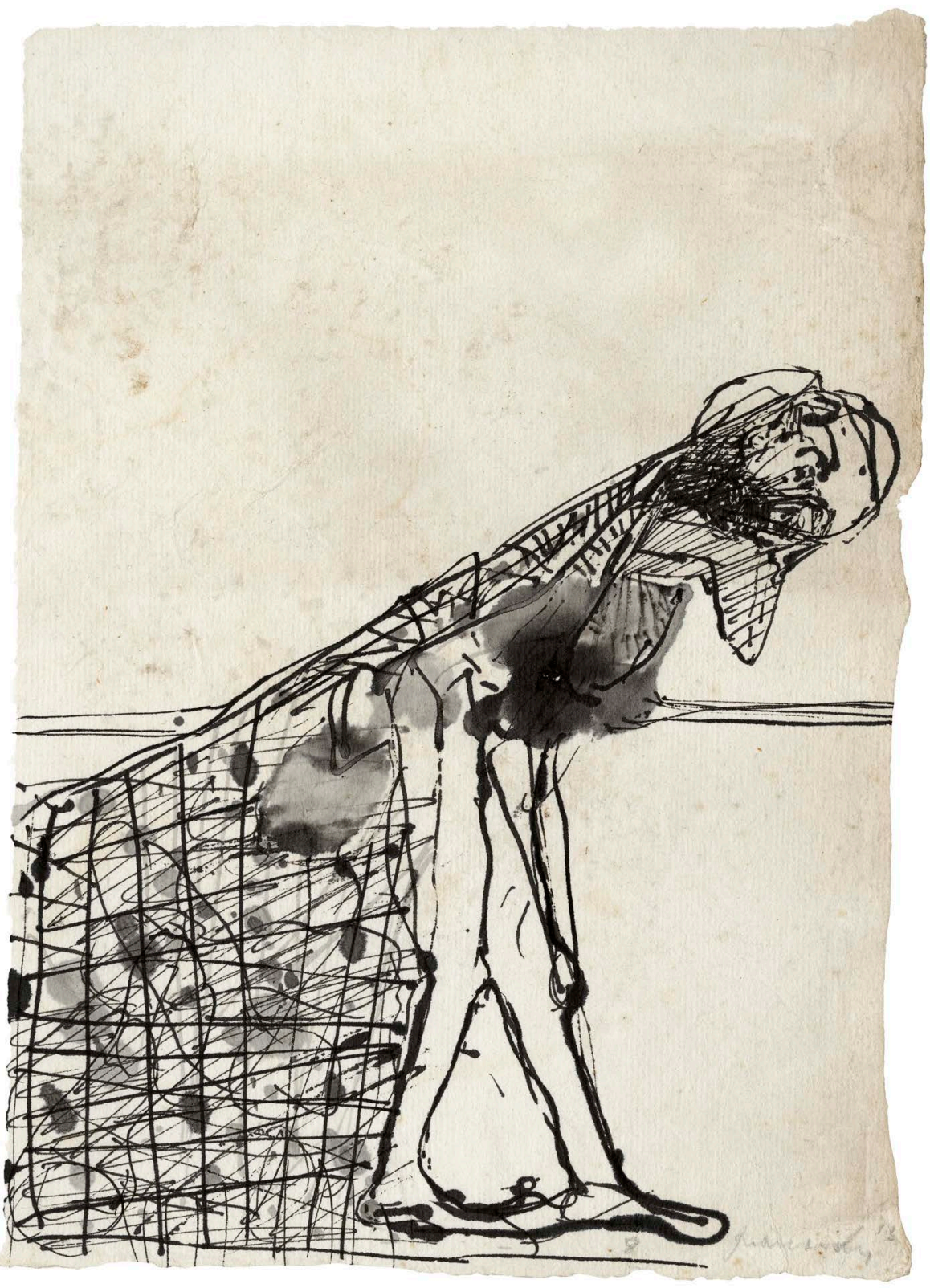

Illustration af Peter Brandes til oversattelsen af oldtidssagaerne. 
et højt, knejsende snit - som en stavkirke eller kølen på et vikingeskib. Peter Brandes vil ikke afbilde scener eller bataljer, men forsøge at indkredse eller studere en række nordiske arketyper eller stemninger og situationer: en figur med et fiskenet, en grubler, en mand med økse, en mand der løfter en sten, osv.

\section{Afsluttende}

Arne Magnussons håndskrifter gemmer på en uvurderlig skat; den indeholder noget af det bedste, som verdenslitteraturen kan fremvise. Vores tid og samtidens smag er (selvfølgelig) en anden end 1800-tallets: Vi kan i dag i langt højere grad goutere det skæve, manierede,

\section{Noter}

1 Larsen og Topsøe-Jensen 1952, s. 18.

2 Lassen 2008.

3 Jón Helgason (udg.) 1942, s. 72.

4 Jf. Lassen 2014 for en oversigt over disse udgaver.

5 Lassen 2014.

6 N.M. Petersen 1841, s. 360.

7 Samme 1840, s. 322.

8 Samme 1844, s. 281.

9 Arne Magnusson 1916, s. 66. fabulerende og overraskende - og vi læser ikke sagaerne som vidnesbyrd om Nordens ældste historie - i det mindste ikke som sandfærdige vidnesbyrd. Vi læser sagaerne som en del af den europæiske litteraturhistorie, ja, som verdenslitteratur. Jeg tror, at vores samtid netop er den rette tid til at (re-)introducere sagagenrerne i al deres frodige mangfoldighed, fra de famlende, stakkaterede sagaer til de fuldendte og finpudsede beretninger, fra de alvorlige og underspillede til de humørfyldte og overdrevne. Hvis vi skal være værdige arvtagere efter Arne Magnusson, må vi - billedlig talt - åbne hans skattekiste, for hele denne levende litteratur skal læses.

10 Jf. Wilson 2006.

11 Citater fra islændingesagaerne er fra de nye oversættelser.

12 "prýtr ok fyrr seinan penna en hans [Hrólfs] snilldarverk", egl. "en langsom pen vil løbe tør før [Rolfs] geniale bedrifter".

13 Jf. Lassen 2012.

14 Rafn 1829, bd. 1, s. xxiv. 


\section{Litteratur}

Abrahamson, Werner (overs.). 17781779. Gunnlaugs Saga. I Det almindelige Danske Bibliothek, 1778, bd. 4, s. 280-319; 1779, bd. 1, s. 25-45. København.

Detter, Ferdinand (udg.). 1891. Zwei fornaldarsögur (Hrólfs saga Gautrekssonar und Asmundarsaga kappabana) nach Cod. Holm 7, 4to. Halle a. S.

Gunnarsson, Gunnar. 1926. "Sagaen i dansk Dragt”. Kronik. Politiken 6.12.1926.

Helgason, Jón (udg.). 1942. Úr bréfabókum Brynjólfs Sveinssonar. Safn Fræðafélagsins um Ísland og Íslendinga, 12. København.

Horn, Fr. Winkel (overs.). 1871-1876. Billeder af Livet paa Island: Islandske Sagaer, bd. 1-3. København.

Kyrre, Hans, Johannes V. Jensen og Gunnar Gunnarsson (red.). 1930-1931.De islandske Sagaer, bd. 1-3. København.

Lassen, Annette. 2008. "Vølvens rap: H.C. Andersens norrøne debut". I Det norrone og det nationale: Brugen af Islands gamle litteratur i nationale sammenhenge i Norge, Sverige, Island, Storbritannien, Tyskland og Danmark. Red. Annette Lassen. Reykjavík, s. 201-218.

Lassen, Annette. 2012. “Origines gentium and the Learned Origin of Fornaldarsögur Nordurlanda”. I Fornaldarsögur Nordurlanda: Origins and Development. Red. Annette Lassen, Agneta Ney og Ármann Jakobsson. Reykjavík, s. 35-58.

Lassen, Annette. 2014. "N.M. Petersens sagaoversættelser." I N.M. Petersen: Et mindeskrift. Red. Frans Gregersen,
Anne Mette Hansen \& Viggo Bank Jensen. København, s. 55-78.

Lassen, Annette (red.). 2014. Islandingesagaerne. Reykjavík.

Larsen, Svend \& H. Topsøe-Jensen. 1952. H.C. Andersens eget liv i billeder. København.

Magnusson, Arne. 1916. Brevveksling med Torfeus. Udg. Kr. Kaalund. København.

Nitter, Truid (overs.). 1738. En Historie om Eigill Skallagrimsøn. Udsat af Islansk paa Latin, og af Latin paa Dansk, og nu forbedret med nogle Vers og Riim. S. 1.

Petersen, N.M. (overs.). 1839-1844. Historiske Fortellinger om Islandernes Ferd hjemme og ude, bd. 1-4. København.

Rafn, C.C. (overs.). 1821-1826. Nordiske Kempe-Historier. København.

Rafn, C.C. (udg.). 1829-1830. Fornaldar Sögur Nordrlanda eptir gömlum handritum. København.

Rafn, C.C. (overs.). 1829-1830. Nordiske Fortids-Sagaer. København.

Rahbek, Knud Lyhne (overs.). 18191821. Nordiske Fortellinger, bd. 1-2. København.

Vigfússon, Guðbrandur (overs.). 1860. Udtog af Bárðarsaga. I Bárðarsaga Snefellsáss, Viglundarsaga, Dórdarsaga, Draumavitranir, Völsapáttr.

København, s. 145-158.

Wilson, Kendra. 2006. "Króka-Refs saga as Science Fiction: Technology, Magic and the Materialist Hero. I The Fantastic in Old Norse/Icelandic Literature. Sagas and the British Isles. Red. John. McKinnell, David Ashurst \& Donata Kick. Durham, 1064-1070. 